\title{
Polymorphisms of Cytochrome P450 Genes in Three Ethnic Groups from Russia
}

\author{
Gülnaz Korytina', Olga Kochetova', Leysan Akhmadishina', Elena Viktorova², Tatyana Victorova' \\ ${ }^{1}$ Institute of Biochemistry and Genetics, Genomics, Ufa, Russian Federation \\ ${ }^{2}$ George-August University of Göttingen, Genomics, Göttingen, Germany
}

\begin{abstract}
Objective: To determine the prevalence of the most common allelic variants of CYP1A1, CYP1A2, CYP1B1, CYP2C9, CYP2E1, CYP2F1, CYP2J2 and CYP2S1 in a representative sample of the three ethnic groups (Russians, Tatars and Bashkirs) from Republic of Bashkortostan (Russia), and compare the results with existing data published for other populations.
\end{abstract}

Material and Methods: CYPs genotypes were determined in 742 DNA samples of healthy unrelated individuals representative of three ethnic groups. The CYPs gene polymorphisms were examined using the PCR-RLFP method.

Results: Analysis of the CYP1A1 (rs1048943, rs4646903), CYP1A2 (rs762551), CYP2E1 (rs2031920) allele, genotype and haplotype frequencies revealed significant differences among healthy residents of the Republic of Bashkortostan of different ethnicities. Distribution of allele and genotype frequencies of CYP1A2 (rs35694136), CYP1B1 (rs1056836), CYP2C9 (rs1799853, rs1057910), CYP2F1 (rs11399890), CYP2J2 (rs890293), CYP2S1 (rs34971233, rs338583) genes were similar in Russians, Tatars, and Bashkirs. Analysis of the CYPs genes allele frequency distribution patterns among the ethnic groups from the Republic of Bashkortostan in comparison with the different populations worldwide was conducted.

Conclusion: The peculiarities of the allele frequency distribution of CYPs genes in the ethnic groups of the Republic of Bashkortostan should be taken into consideration in association and pharmacogenetic studies. The results of the present investigation will be of great help in elucidating the genetic background of drug response, susceptibility to cancer and complex diseases, as well as in determining the toxic potentials of environmental pollutants in our region.

Key Words: Pharmacogenetics, genetic polymorphism, ethnic-related differences CYPs variants in three ethnic groups from Russia

Received: 05.10.2011

Accepted: 22.05.2012

\section{Introduction}

The human cytochrome P450 superfamily (CYPs) includes 57 functionally active genes. Genetic polymorphisms in CYPs may influence inter-individual variation in human sensitivity to damaging environmental factors and predisposition to complex diseases.

CYPs belong to a group of enzymes that metabolize hundreds of various compounds. Enzymes of the group facilitate the incorporation of activated oxygen directly into a substrate molecule to produce a more hydrophilic oxidized product and water molecule. CYPs perform two important functions in mammals: they are involved in metabolizing endogenous lipophilic substrates, such as steroids, arachidonates, and retinoids, and in transforming exogenous compounds. CYPs play a role in the activation of many procarcinogens $(1,2)$.

Enzymes of the CYP1, CYP2, and CYP3 families are involved in metabolizing exogenous substrates, while members of other families are involved in the metabolism of endogenous compounds such as vitamin $D$, retinoic acid, cholesterol and steroid hormones. Expression of the CYPs genes is regulated via several pathways. Inducible transcription is activated via a ligand-specific receptor, while constitutive expres- sion involves tissue specific factors, each binding to a certain regulatory element in the $5^{\prime}$ terminal gene region (1-4).

CYPs gene polymorphisms differ markedly in frequency among different ethnic and racial groups $(2,3,5,6)$.

The Republic of Bashkortostan is located in the Southern part of the Urals. It is a sovereign state under the jurisdiction of Russia. The Republic of Bashkortostan has an exclusive location on the border of two continents - Europe and Asia. Representatives of 70 nations and ethnicities live in the Republic of Bashkortostan, including Russians (39.3\%), Tatars (28.4\%) and Bashkirs (21.9\%). This region since ancient times was the scene of intense ethnic and cultural interactions of ethnic groups of different origins. The current population of the Republic of Bashkortostan is extremely heterogeneous in its ethnic composition, linguistic and anthropological background (6). The study of autosomal DNA markers showed the presence in the gene pool of peoples of Bashkortostan a significant proportion of Caucasoid traits -50 to $90 \%$. Thus, caught at the border between Europe and Asia, these peoples have preserved traces of the mixing of two races, -one from the East, and anotherfrom the West (7). In addition, it was found that the similarity of language plays a smaller role than the geographical proximity of populations. If, for example, people from the Russian 
Ryazan and Kursk regions have only 2-3\% of Mongoloid types mtDNA, while the Russians who live on the border between Europe and Asia, have $10-12 \%$. This is due to their mixing with the Turkic peoples in the South Ural region (8).

Activity of enzymes, as well as the rate of the metabolic processes in the human body and, consequently, frequency of the incidence for pathological diseases in the range of different populations vary substantially among them. This variability not only accounts for different environmental and social conditions of the population, lifestyle and diet, but importantly, the genetic background which causes variability in metabolic parameters. It follows that the pathogenetic relationships between some genetic characteristics with individual response to environmental factors can be detected only when the analysis includes consideration of specific population characteristics of study groups, particularly ethnic heterogeneity.

The purpose of the present study was to investigate the prevalence of the most common allelic variants of CYP1A1, CYP1A2, CYP1B1, CYP2C9, CYP2E1, CYP2F1, CYP2J2, and CYP2S1 in a representative sample of the three ethnic groups (Russians, Tatars and Bashkirs) from the Republic of Bashkortostan (Russia), and comparing the results with existing data published for other populations.

\section{Material and Methods}

\section{DNA samples}

The total number of 742 DNA samples of healthy unrelated individuals, representatives of three ethnic groups, historically dispersed over the territory of the Republic of Bashkortostan (South Ural Region of Russia) have been analyzed in this study. There were 319 individuals classified as Russians, 279 Tatars, and 144 Bashkirs.

Prior to implementation, the present study was approved by the Independent Ethics Committee (IEC) of the Institute of Biochemistry and Genetics, Ufa Scientific Centre of Russian Academy of Sciences, Ufa, Russia. Blood samples were collected during research expeditions in 2004-2008. Ethnic origin (up to the third generation) was derived by direct interviews with examined persons. Peripheral blood samples were collected into EDTA tubes and stored at $-20^{\circ} \mathrm{C}$ until DNA isolation. Genomic DNA was isolated from white blood cells (10 $\mathrm{mL}$ ) by a standard procedure of phenol-chloroform extraction (9). All DNA samples used in the study were anonymous.

\section{PCR-RFLP analysis}

The CYPs gene polymorphisms and identification method of the polymorphic alleles used in this study are presented in Table 1. The CYPs genes polymorphisms were examined using polymerase chain reaction (PCR) with Thermus aquaticus DNA polymerase Fermentas (Lithuania) and subsequent digestion of the product with restriction endonucleases from SibEnzyme (Russia) and Fermentas (Lithuania). PCR was run on a 2720 thermal cycler (Applied Biosystems, USA) under the conditions described earlier (see reference in Table 1). Alleles and haplotypes nomenclature wais given according to www. imm.ki.se/CYPalleles. The output from amplification and restriction procedures was analyzed by vertical PAGE in 6-8\% gel (acrylamide-methylene bisacrylamide 29:1) in Tris-borate (TBE) at $200-300 \mathrm{~V}(10 \mathrm{~V} / \mathrm{cm})$. Following the electrophoresis procedure, gels were stained with $0.1 \mu \mathrm{g} / \mathrm{mL}$ ethidium bromide for $15 \mathrm{~min}$ and photographed in transmitted UV light. Alleles were identified against a marker 100 bp DNA ladder Fermentas (Lithuania).

\section{Statistical analysis}

Allele and genotype frequencies of the polymorphisms, as well as errors, and confidence intervals were calculated in the STATISTICA v.6.0 program (www.statistica.com StatSoft Inc., USA). Genotype frequency distributions were tested for agreement with the Hardy-Weinberg equilibrium performing $\chi 2$ test using electronic calculator [http://www.genes.org.uk/ software/hardy-weinberg.html]. CYP1A1 and CYP1A2 haplotype frequencies, and the values of normalized linkage disequilibrium coefficient (Lewontin's coefficient), D', were computed using the expectation maximization algorithm and maximum likelihood method with the Haploview 4.2 (10). Differences in allele, genotype and haplotype frequencies distributions between the ethnic groups were tested for significance by the $\chi 2$ test using the STATISTICA v. 6.0 programs (www.statistica. com StatSoft Inc., USA) and Haploview 4.2 (10).

\section{Results}

Polymorphic variants of the CYPs genes were examined in three ethnic groups residing in the Republic of Bashkortostan. Genotype frequencies distributions of the CYPs genes in all ethnic groups were examined for Hardy-Weinberg proportions. Statistical analysis showed that the genotype frequencies of the CYPs polymorphism do not deviate from the Hardy-Weinberg proportions in all the considered ethnic groups (Russians, Tatars and Bashkirs). Observed counts and frequencies of the variant genotypes, alleles and halpotypes of the CYP1A1, CYP1A2, CYP1B1, CYP2C9, CYP2E1, CYP2F1, CYP2J2 and CYP2S1 are shown in Table 2, 3 and 4.

\section{CYP1A1}

Significant interethnic differences were found for the distribution of the CYP1A1 polymorphism rs1048943, 2454A>G $\left(\chi^{2}=14.466, d f=4, p=0.006\right.$ and $\chi^{2}=10.03, d f=2, p=0.007$, for genotype and allele, respectively) (Table 2, 3). For Russians and Tatars, the genotype and allele frequencies distributions were similar ( $p=0.49$ and $p=0.302$, respectively). Bashkirs have significantly different genotype frequency distributions from both Tatars $\left(\chi^{2}=7.588, d f=2, p=0.023\right)$ and Russians $\left(\chi^{2}=12.67\right.$, $\mathrm{df}=2, \mathrm{p}=0.002)$. Bashkirs also differ in the allele frequency distributions from Russians $\left(\chi^{2}=9.062, d f=2, p=0.003\right)$.

Genotype and allele frequencies of the CYP1A1 polymorphism rs4646903, 3798T>C were derived. Significant differences between Russians, Tatars, and Bashkirs in terms of this polymorphism were observed $\left(\chi^{2}=17.39, \mathrm{df}=4, \mathrm{p}=0.002\right.$ and $\chi^{2}=16.094$, $\mathrm{df}=2, \mathrm{p}=0.0001$, for genotype and allele, respectively). Pairwise comparison of Russian and Tatar groups did not reveal any differences in the genotype or allele frequency distributions of this polymorphism ( $p=0.117$ and $p=0.105$, respectively). The group of Bashkirs was found to be significantly different in the genotype and allele frequencies distributions from both Russians $\left(\chi^{2}=16.808, d f=2, p=0.0001\right.$ and $\chi^{2}=15.352, d f=2, p=0.00001$, respectively) and Tatars $\left(\chi^{2}=6.841, d f=2, p=0.033\right.$ and $\chi^{2}=5.237$, $d f=2, p=0.022$, respectively) (Table 2,3$)$. 
Table 1. The CYPs genes polymorphisms used in this study

\begin{tabular}{|c|c|c|c|c|c|}
\hline Gene & $\begin{array}{l}\text { Chromosomal } \\
\text { localization }\end{array}$ & Polymorphism & RefSNP accession & $\begin{array}{c}\text { Allele nomenclature } \\
\text { according to } \\
\text { www.imm.ki.se/CYPalleles }\end{array}$ & $\begin{array}{l}\text { Method of detection, } \\
\text { restriction enzyme }\end{array}$ \\
\hline CYP1A1 & $15 q 24.1$ & $2454 A>G, 1462 V$ & rs1048943 & $\begin{array}{l}\text { CYP1A1*1- wild (2454A) } \\
\text { CYP1A1*2C-(2454G) }\end{array}$ & PCR-RLFP (Hindll) \\
\hline CYP1A1 & $15 q 24.1$ & $3798 \mathrm{~T}>\mathrm{C}$ & rs4646903 & $\begin{array}{l}\text { CYP1A1*1- wild (3798T } \\
\text { CYP1A1*2A-(3798C) }\end{array}$ & PCR-RLFP (Mspl) \\
\hline CYP1A2 & $15 q 24.1$ & $-163 C>A$ & rs762551 & $\begin{array}{l}\text { CYP1A2*1A- wild }(-163 C) \\
\text { CYP1A2*1F-(-163A) }\end{array}$ & PCR-RLFP (Bsp120I) \\
\hline CYP1A2 & $15 q 24.1$ & -2467delT & rs35694136 & $\begin{array}{l}\text { CYP1A2*1A -wild (-2467T) } \\
\text { CYP1A2*1D-(-2467delT) }\end{array}$ & PCR-RLFP (FauNDI) \\
\hline CYP1B1 & $2 \mathrm{p} 22.2$ & $4326 C>G, L 432 V$ & rs1056836 & $\begin{array}{l}\text { CYP1B1*1-wild (4326C) } \\
\text { CYP1B1*3-(4326G) }\end{array}$ & PCR-RLFP (Pstl) \\
\hline CYP2C9 & $10 q 23.33$ & $3608 \mathrm{C}>\mathrm{T}, \mathrm{R} 144 \mathrm{C}$ & rs1799853 & $\begin{array}{l}\text { CYP2C9*1A-wild }(3608 C) \\
\text { CYP2C } 9 * 2 A-(3608 T)\end{array}$ & PCR-RLFP (Bme18I) \\
\hline CYP2C9 & $10 q 23.33$ & $42614 A>C, 1359 L$ & rs1057910 & $\begin{array}{l}\text { CYP2C9*1A-wild (42614A) } \\
\text { CYP2C9*3A-(42614C) }\end{array}$ & PCR-RLFP (Zsp2I) \\
\hline CYP2E1 & $10 q 26.3$ & $-1053 C>T$ & rs2031920 & $\begin{array}{l}\text { CYP2E1*1A-wild(-1053C) } \\
\text { CYP2E1*5B-(-1053T) }\end{array}$ & PCR-RLFP (Pstl) \\
\hline CYP2F1 & $19 q 13.2$ & c.14_15insC & rs11399890 & $\begin{array}{c}\text { CYP2F2*1-wild } \\
\text { CYP2F2*2A-(c.14_15insC) }\end{array}$ & PCR-RLFP (HaellI) \\
\hline CYP2J2 & $1 p 32.1$ & $-76 G>T$ & rs890293 & $\begin{array}{l}\text { CYP2J2*1-wild (-76G) } \\
\text { CYP2J2*7-(-76T) }\end{array}$ & PCR-RLFP (AluBI) \\
\hline CYP2S1 & $19 q 13.2$ & $13106 \mathrm{C}>\mathrm{T}, \mathrm{P} 466 \mathrm{~L}$ & rs34971233 & $\begin{array}{l}\text { CYP2S1*1A-wild (13106C) } \\
\text { CYP2S1*3-(13106T) }\end{array}$ & PCR-RLFP (Eco24I) \\
\hline CYP2S1 & $19 q 13.2$ & 13255A>G, 3' UTR & rs338583 & $\begin{array}{l}\text { CYP2S1*1A-wild (13255A) } \\
\text { CYP2S1*1H-(13255G) }\end{array}$ & PCR-RLFP (Smal) \\
\hline
\end{tabular}

The frequencies of haplotypes of the CYP1A1 rs1048943, 2454A $>G$ and rs4646903, 3798T $>C$ polymorphisms in three ethnic groups were analyzed (Table 4). Significant differences were found between the groups of different ethnicity $\left(\chi^{2}=18.913, d f=6, p=0.00001\right)$. It was concluded that Bashkirs significantly differ in CYP1A1 haplotype frequency distribution from Russians $\left(\chi^{2}=17.454, d f=3, p=0.0001\right)$. No significant difference among Tatars and Bashkirs was detected.

\section{CYP1A2 gene}

The genotype and allele frequency distributions of CYP1A2 polymorphism rs35694136, -2467delT in Russians, Tatars, and Bashkirs were similar (Table 2). There was neither significant differences between Russians and Tatars nor between Tatars and Bashkirs. However, Russians and Bashkirs appear to have significantly different allele frequency $\left(\chi^{2}=4.649, d f=1, p=0.031\right)$. The genotype and allele frequency distribution of the CYP1A2 polymorphism rs762551, $-163 \mathrm{C}>\mathrm{A}$ significantly varies between Russians, Tatars, and Bashkirs $\left(\chi^{2}=10.59, \mathrm{df}=4, \mathrm{p}=0.032\right.$ and $\chi^{2}=8.147, d f=2, p=0.017$, for genotype and allele, respectively). The group of Tatars significantly deviate in the genotype and allele frequency distribution from Russians $\left(\chi^{2}=8.529\right.$, $d f=2, p=0.014$ and $\left.\chi^{2}=7.771, d f=2, p=0.005\right)$. These differences are due to a high frequency of CYP1A2*1F*1F genotype and CYP1A2*1F allele in Tatars (Table 2, 3). Pairwise comparisons did not identify any significant difference between Russians and Bashkirs ( $p=0.27$ and $p=0.414$, for genotype and allele, respectively) and between Tatars and Bashkirs ( $p=0.228$ and $p=0.164$, for genotype and allele, respectively).
Analysis of the CYP1A2 rs35694136, -2467delT and rs762551, -163C>A polymorphisms haplotypes frequencies detected significant differences among healthy residents of Bashkortostan of different ethnicities $\left(\chi^{2}=20.537, \mathrm{df}=6, \mathrm{p}=0.0001\right)$. In fact, results of the pairwise comparisons tests suggest similarity for the groups of Russians and Tatars $\left(\chi^{2}=7.237, d f=3\right.$, $p=0.084)$, whereas Bashkirs were found to be significantly different from both Russians and Tatars $\left(\chi^{2}=12.187, d f=3, p=0.009\right.$ and $\left.\chi^{2}=27.576, d f=3, p=0.0001\right)$. The frequency of CYP1A2*1D and CYP1A2*1F is shown in Table 4.

In the groups of Russians and Bashkirs, linkage between the alleles of the CYP1A2 polymorphisms rs35694136, -2467delT and rs762551, $-163 C>A$ did not appear $\left(D^{\prime}=0.353\right.$ and $D^{\prime}=0.175$, respectively). Linkage between the alleles of the $C Y$ $P 1 A 2$ polymorphisms in Tatars was found $\left(D^{\prime}=0.601\right)$ (Table 5$)$. The ethnic group of Tatars was characterized by a substantially increased frequency of haplotype CYP1A2*1L (18.51\%).

Linkage between the alleles of the CYP1A1 (rs1048943, 2454A $>\mathrm{G}$ ) and CYP1A2 (rs35694136,-467delT) polymorphisms in Bashkirs $\left(D^{\prime}=0.746\right)$ and Tatars $\left(D^{\prime}=0.724\right)$ were found. The values of $D^{\prime}$ in Russians was 0.420 (Table 5).

\section{CYP1B1 gene}

The genotype and allele frequencies of the CYP1B1 polymorphism rs1056836, 4326C>G, L432V were compared among the three ethnic groups. It should be noticed that the frequency of heterozygous genotype was high in all ethnic groups $(54.03,55.93$ and $51.91 \%$, respectively). Russians, Tatars and Bashkirs show a Caucasian genotype frequency distribution of CYP1B1 (Table 2, 3). 
Table 2. Frequencies of the CYPs genes genotypes among ethnic groups of Republic of Bashkortostan

\begin{tabular}{|c|c|c|c|c|c|c|c|}
\hline $\begin{array}{l}\text { Gene, } \\
\text { polymorphism }\end{array}$ & RefSNP & Genotype & $\begin{array}{c}\text { Genotype } \\
\text { according } \\
\text { to www.imm.ki.se/ } \\
\text { CYPalleles } \\
4\end{array}$ & $\begin{array}{l}\text { Russian } \\
\text { n (\%) }\end{array}$ & $\begin{array}{l}\text { Tatars } \\
\text { n (\%) }\end{array}$ & $\begin{array}{l}\text { Bashkirs } \\
\text { n (\%) }\end{array}$ & 8 \\
\hline $\begin{array}{l}\text { CYP1A1 } \\
2454 A>G\end{array}$ & rs1048943 & $\begin{array}{l}A / A \\
A / G \\
G / G\end{array}$ & $\begin{array}{l}\text { CYP1A1*1A*1A } \\
\text { CYP1A } 1 * 1 A^{*} 2 C \\
\text { CYP1A } 1 * 2 C * 2 C\end{array}$ & $\begin{array}{c}285(90.76) \\
28(8.92) \\
1(0.32)\end{array}$ & $\begin{array}{c}214(88.07) \\
27(11.11) \\
2(0.82)\end{array}$ & $\begin{array}{c}106(79.10) \\
28(20.90) \\
0\end{array}$ & 0.006 \\
\hline $\begin{array}{l}\text { CYP1A1 } \\
3798 T>C\end{array}$ & rs4646903 & $\begin{array}{l}\mathrm{T} / \mathrm{T} \\
\mathrm{T} / \mathrm{C} \\
\mathrm{C} / \mathrm{C}\end{array}$ & $\begin{array}{l}\text { CYP1A1*1A*1A } \\
\text { CYP1A } 1 * 1 A * 2 A \\
\text { CYP1A } 1 * 2 A * 2 A\end{array}$ & $\begin{array}{c}216(75.79) \\
66(23.16) \\
3(1.05)\end{array}$ & $\begin{array}{c}164(70.69) \\
60(25.86) \\
8(3.45)\end{array}$ & $\begin{aligned} 78 & (57.35) \\
52 & (38.24) \\
6 & (4.41)\end{aligned}$ & 0.002 \\
\hline $\begin{array}{l}\text { CYP1A2 } \\
\text {-2467delT }\end{array}$ & rs35694136 & $\begin{array}{c}\mathrm{n} / \mathrm{n} \\
\mathrm{n} / \mathrm{delT} \\
\text { delT/delT }\end{array}$ & $\begin{array}{l}\text { CYP1A2*1A*1A } \\
\text { CYP1A2*1A*1D } \\
\text { CYP1A2*1D*1D }\end{array}$ & $\begin{array}{c}198(67.58) \\
84(28.67) \\
11(3.75)\end{array}$ & $\begin{array}{c}150(60.73) \\
86(34.82) \\
11(4.45)\end{array}$ & $\begin{array}{cc}82 & (58.57) \\
47 & (33.57) \\
11 & (7.86)\end{array}$ & 0.149 \\
\hline $\begin{array}{l}\text { CYP1A2 } \\
-163 C>A\end{array}$ & rs762551 & $\begin{array}{l}C / C \\
C / A \\
A / A\end{array}$ & $\begin{array}{l}\text { CYP1A2*1A*1A } \\
\text { CYP1A2*1A*1F } \\
\text { CYP1A2*1F*1F }\end{array}$ & $\begin{array}{c}52(17.11) \\
148(48.68) \\
104(34.21)\end{array}$ & $\begin{aligned} 24 & (9.80) \\
114 & (46.53) \\
107 & (43.67)\end{aligned}$ & $\begin{array}{ll}16 & (11.35) \\
76 & (53.90) \\
49 & (34.75)\end{array}$ & 0.032 \\
\hline $\begin{array}{l}\text { CYP1B1 } \\
4326 C>G\end{array}$ & rs1056836 & $\begin{array}{l}C / C \\
C / G \\
G / G\end{array}$ & $\begin{array}{l}\text { CYP1B1*1*1 } \\
\text { CYP1B1*3*1 } \\
\text { CYP1B1*3*3 }\end{array}$ & $\begin{array}{c}61(20.47) \\
161(54.03) \\
76(25.50)\end{array}$ & $\begin{array}{cc}62 & (22.96) \\
151 & (55.93) \\
57 & (21.11)\end{array}$ & $\begin{array}{ll}31 & (23.66) \\
68 & (51.91) \\
32 & (24.43)\end{array}$ & 0.563 \\
\hline $\begin{array}{l}\text { CYP2C9 } \\
3608 C>T\end{array}$ & rs1799853 & $\begin{array}{l}\mathrm{C} / \mathrm{C} \\
\mathrm{C} / \mathrm{T} \\
\mathrm{T} / \mathrm{T}\end{array}$ & $\begin{array}{l}\text { CYP2C9*1A*1A } \\
\text { CYP2C9*1A*2A } \\
\text { CYP2C9*2A*2A }\end{array}$ & $\begin{array}{c}95(84.82) \\
17(15.18) \\
0\end{array}$ & $\begin{array}{c}96(89.72) \\
11(10.28) \\
0\end{array}$ & $\begin{array}{c}50(87.72) \\
7(12.28) \\
0\end{array}$ & 0.67 \\
\hline $\begin{array}{l}\text { CYP2C9 } \\
42614 A>C\end{array}$ & rs1057910 & $\begin{array}{l}A / A \\
A / C \\
C / C\end{array}$ & $\begin{array}{l}\text { CYP2C9*1A*1A } \\
\text { CYP2C9*1A*3A } \\
\text { CYP2C9*3A*3A }\end{array}$ & $\begin{array}{c}109(81.95) \\
24(18.05) \\
0\end{array}$ & $\begin{array}{c}115(89.15) \\
14(10.85) \\
0\end{array}$ & $\begin{array}{c}57(87.69) \\
8(12.31) \\
0\end{array}$ & 0.754 \\
\hline $\begin{array}{l}\text { CYP2E1 } \\
-1053 C>T\end{array}$ & rs2031920 & $\begin{array}{l}\mathrm{C} / \mathrm{C} \\
\mathrm{C} / \mathrm{T} \\
\mathrm{T} / \mathrm{T}\end{array}$ & $\begin{array}{l}\text { CYP2E1*1A*1A } \\
\text { CYP2E1*1A*5B } \\
\text { CYP2E1*5B*5B }\end{array}$ & $\begin{aligned} 302 & (94.67) \\
17 & (5.33) \\
& 0\end{aligned}$ & $\begin{aligned} 252 & (90.32) \\
27 & (9.68) \\
& 0\end{aligned}$ & $\begin{array}{c}114(86.36) \\
18(13.64) \\
0\end{array}$ & 0.011 \\
\hline $\begin{array}{l}\text { CYP2F1 } \\
\text { c.14_15insC }\end{array}$ & rs11399890 & $\begin{array}{l}\text { wild type/wild type } \\
\text { wild type/ ins } \\
\text { ins/ ins }\end{array}$ & $\begin{array}{c}\text { CYP2F1*1*1 } \\
\text { CYP2F1*1*2A } \\
\text { CYP2F1*2A*2A }\end{array}$ & $\begin{array}{c}210(67.31) \\
94(30.13) \\
8(2.56)\end{array}$ & $\begin{array}{c}162(64.03) \\
75(29.64) \\
16(6.32)\end{array}$ & $\begin{array}{cl}89 & (61.81) \\
52 & (36.11) \\
3 & (2.08)\end{array}$ & 0.074 \\
\hline $\begin{array}{l}\text { CYP2J2 } \\
-76 G>T\end{array}$ & rs890293 & $\begin{array}{c}\mathrm{G} / \mathrm{G} \\
\mathrm{G} / \mathrm{T} \\
\mathrm{T} / \mathrm{T}\end{array}$ & $\begin{array}{l}\text { CYP2J2*1*1 } \\
\text { CYP2J2*1*7 } \\
\text { CYP2J2*7*7 }\end{array}$ & $\begin{aligned} 196 & (90.32) \\
21 & (9.68) \\
& 0\end{aligned}$ & $\begin{aligned} 165 & (92.70) \\
13 & (7.30) \\
0 & \end{aligned}$ & $\begin{array}{cl}99 & (97.06) \\
3 & (2.94) \\
0 & \end{array}$ & 0.101 \\
\hline $\begin{array}{l}\text { CYP2S1 } \\
13106 C>T\end{array}$ & rs34971233 & $\begin{array}{l}\mathrm{C} / \mathrm{C} \\
\mathrm{C} / \mathrm{T} \\
\mathrm{T} / \mathrm{T}\end{array}$ & $\begin{array}{c}\text { CYP2S1*1A*1A } \\
\text { CYP2S1*1A*3 } \\
\text { CYP2S1*3*3 }\end{array}$ & $\begin{array}{cl}178 & (83.57) \\
34 & (15.96) \\
1 & (0.47)\end{array}$ & $\begin{array}{c}156(82.54) \\
31(16.40) \\
2(1.06)\end{array}$ & $\begin{aligned} 88 & (83.81) \\
15 & (14.29) \\
2 & (1.90)\end{aligned}$ & 0.790 \\
\hline $\begin{array}{l}\text { CYP2S1 } \\
13255 A>G\end{array}$ & rs338583 & $\begin{array}{l}A / A \\
A / G \\
G / G\end{array}$ & $\begin{array}{l}\text { CYP2S1*1A*1A } \\
\text { CYP2S1*1A*1H } \\
\text { CYP2S1*1H*1H }\end{array}$ & $\begin{array}{c}129(60.56) \\
67(31.46) \\
17(7.98)\end{array}$ & $\begin{array}{c}111(58.73) \\
60(31.75) \\
18(9.52)\end{array}$ & $\begin{array}{ll}57 & (54.29) \\
35 & (33.33) \\
13 & (12.38)\end{array}$ & 0.737 \\
\hline
\end{tabular}

CYP2C9 gene

Analysis of the CYP2C9 (rs1799853, 3608C >T, R144C) and (rs1057910, 42614A >C, I359L) polymorphism did not reveal statistically significant differences in genotype and allele frequencies among the ethnic groups of Russians, Tatars, and Bashkir (Table 2, 3).

\section{CYP2E1 gene}

The genotype and allele frequencies of the CYP2E1 polymorphism rs2031920, $-1053 C>T$ in the three ethnic groups were analyzed. Significant differences among Russians, Tatars, and Bashkirs were detected $\left(\chi^{2}=9.105, \mathrm{df}=2, \mathrm{p}=0.011\right.$ and $\chi^{2}=8.7, \mathrm{df}=2, \mathrm{p}=0.013$, for genotype and allele, respectively). The allele frequencies of the CYP2E1 (rs2031920, -1053C>T) polymorphism in Bashkirs were significantly different from those in Russians $\left(\chi^{2}=7.56, d f=2, p=0.006\right.$, for allele) (Table 3).

\section{CYP2F1 gene}

The genotype and allele frequencies of the rs11399890, c.14_15insC polymorphism of CYP2F1 in the three ethnic groups were analyzed. Significant differences among Russians, Tatars, and Bashkirs were not detected (Table 2, 3).

\section{CYP2J2 gene}

Analysis of the CYP2J2 rs890293, -76G>T polymorphism did not reveal statistically significant differences in genotype and allele frequencies between the ethnic groups of Russians, Tatars, and Bashkirs (Table 2, 3). However, a higher frequency of CYP2J2*1*7 genotype was observed in Russians (9.68\%), while in Tatars and Bashkirs the frequencies of this genotype were 7.3 and $2.08 \%$, respectively. The homozygous CYP2J2*7*7 genotype was not observed in considered ethnic groups (Table 3 ). 
Table 3. Frequencies of the CYPs genes alleles among ethnic groups of Republic of Bashkortostan

\begin{tabular}{|c|c|c|c|c|c|c|c|}
\hline $\begin{array}{l}\text { Gene, } \\
\text { polymorphism }\end{array}$ & RefSNP & Alleles & $\begin{array}{c}\text { Genotype } \\
\text { according to } \\
\text { www.imm.ki.se/ } \\
\text { CYPalleles }\end{array}$ & $\begin{array}{c}\text { Russian } \\
\text { n (\%) }\end{array}$ & $\begin{array}{l}\text { Tatars } \\
\text { n (\%) }\end{array}$ & $\begin{array}{c}\text { Bashkirs } \\
\text { n (\%) }\end{array}$ & $\mathbf{P}$ \\
\hline 1 & 2 & 3 & & 4 & 5 & 6 & 7 \\
\hline CYP1A1 & rs1048943 & $A$ & CYP1A1*1A & $598(95.22)$ & 455 (93.62) & $240(89.55)$ & 0.007 \\
\hline $2454 A>G$ & & G & CYP1A1*2C & 30 (4.78) & 31 (6.38) & $28(10.45)$ & \\
\hline CYP1A1 & rs4646903 & $\mathrm{T}$ & CYP1A1*1A & 498 (87.37) & 388 (83.62) & $208(76.47)$ & 0.0001 \\
\hline $3798 T>C$ & & C & CYP1A $1 * 2 A$ & 72 (12.63) & $76(16.38)$ & 64 (23.53) & \\
\hline CYP1A2 & rs762551 & $\mathrm{n}$ & CYP1A2*1A & 106 (18.09) & $386(78.14)$ & $211(75.36)$ & 0.141 \\
\hline$-2467 d e / T$ & & delT & CYP1A2*1D & 480 (81.91) & $108(21.86)$ & 69 (24.64) & \\
\hline CYP1A2 & rs35694136 & C & CYP1A2*1A & $252(41.45)$ & $162(33.06)$ & $108(38.30)$ & 0.017 \\
\hline$-163 C>A$ & & $A$ & CYP1A2*1F & $356(58.55)$ & 328 (66.94) & 174 (61.70) & \\
\hline CYP1B1 & rs1056836 & C & CYP1B1*1 & $313(52.52)$ & 265 (49.07) & $130(49.62)$ & 0.869 \\
\hline $4326 C>G$ & & G & CYP1B1*3 & $283(47.48)$ & $275(50.93)$ & $132(50.38)$ & \\
\hline CYP2C9 & rs1799853 & C & CYP2C9*1A & 207 (92.41) & 203 (94.86) & 107 (93.86) & 0.347 \\
\hline $3608 C>T$ & & $\mathrm{~T}$ & CYP2C9*2A & 17 (7.59) & $11(5.14)$ & 7 (6.14) & \\
\hline CYP2C9 & rs1799853 & C & CYP2C9*1A & 242 (90.98) & 244 (94.57) & $122(93.85)$ & 0.486 \\
\hline $3608 C>T$ & & $\mathrm{~T}$ & CYP2C9*3A & 24 (9.02) & $14(5.43)$ & $8(6.15)$ & \\
\hline CYP2E1 & rs2031920 & C & CYP2E1*1A & $621(97.34)$ & $531(95.16)$ & $246(93.18)$ & 0.013 \\
\hline$-1053 C>T$ & & $\mathrm{~T}$ & CYP2E1*5B & $17(2.66)$ & $27(4.84)$ & $18(6.8)$ & \\
\hline CYP2F1 & rs11399890 & $\mathrm{n}$ & CYP2F1*1 & $514(82.37)$ & 399 (78.85) & $230(79.86)$ & 0.31 \\
\hline c.14_15insC & & ins C & CYP2F1*2A & $110(17.63)$ & 107 (21.15) & $58(20.14)$ & \\
\hline CYP2J2 & rs890293 & G & CYP2J2*1 & 433 (95.16) & 343 (96.35) & 201 (98.53) & 0.136 \\
\hline$-76 G>T$ & & $\mathrm{~T}$ & CYP2J2*7 & $21(4.84)$ & $13(3.65)$ & 3 (1.47) & \\
\hline CYP2S1 & rs34971233 & C & CYP2S1*1A & 390 (91.55) & 343 (90.74) & 191 (90.95) & 0.918 \\
\hline $13106 C>T$ & & $\mathrm{~T}$ & CYP2S1*3 & $36(8.45)$ & $35(9.26)$ & $19(9.05)$ & \\
\hline CYP2S1 & rs338583 & $A$ & CYP2S1*1A & 325 (76.29) & $282(74.60)$ & 149 (70.95) & 0.347 \\
\hline $13255 A>G$ & & G & CYP2S1*1H & $101(23.71)$ & $96(25.40)$ & $61(29.05)$ & \\
\hline
\end{tabular}

Table 4. Frequencies of the CYP1A1, CYP1A2, CYP2S1 haplotypes among ethnic groups of Republic of Bashkortostan

\begin{tabular}{|c|c|c|c|c|c|}
\hline Haplotypes & $\begin{array}{l}\text { Haplotypes according } \\
\text { to www.imm.ki.se/ } \\
\text { CYPalleles) }\end{array}$ & $\begin{array}{c}\text { Russian } \\
\text { n (\%) }\end{array}$ & $\begin{array}{l}\text { Tatars } \\
\text { n (\%) }\end{array}$ & $\begin{array}{c}\text { Bashkirs } \\
\text { n (\%) }\end{array}$ & $\mathbf{P}$ \\
\hline & & CYP1A1 & & & \\
\hline $2455 \mathrm{~A} / 3801 \mathrm{~T}$ & CYP1A1*1A & $461(85.37)$ & 342 (81.82) & 193 (74.23) & 0.00001 \\
\hline $2455 \mathrm{~A} / 3801 \mathrm{C}$ & CYP1A $1 * 2 A$ & $54(10.00)$ & 54 (12.92) & 41 (15.77) & \\
\hline $2455 \mathrm{G} / 3801 \mathrm{~T}$ & CYP1A1*2C & $10(1.85)$ & $5(1.20)$ & $6(2.31)$ & \\
\hline \multirow[t]{2}{*}{$2455 G / 3801 C$} & CYP1A1*2B & $15(2.78)$ & $17(4.07)$ & $20(7.69)$ & \\
\hline & & CYP1A2 & & & \\
\hline$-2467 T /-163 C$ & CYP1A2*1A & $150(26.88)$ & $145(30.85)$ & $82(30.15)$ & 0.0001 \\
\hline -2467delT/-163C & CYP1A2*1D & 309 (55.38) & $225(47.87)$ & $123(45.22)$ & \\
\hline$-2467 T /-163 \mathrm{~A}$ & CYP1A2*1F & $19(3.41)$ & $13(2.77)$ & $21(7.72)$ & \\
\hline \multirow[t]{2}{*}{-2467delT/-163A } & CYP1A2*1L & $80(14.34)$ & $87(18.51)$ & $46(16.91)$ & \\
\hline & & CYP2S1 & & & \\
\hline 13106C/13255A & CYP2S1*1A & $323(76.18)$ & $282(74.60)$ & 149 (70.95) & 0.417 \\
\hline $13106 C / 13255 G$ & CYP2S1*1H & 59 (13.92) & 55 (14.55) & 41 (19.52) & \\
\hline $13106 \mathrm{~T} / 13255 \mathrm{G}$ & CYP2S1*3 & $42(9.91)$ & $41(10.85)$ & $20(9.52)$ & \\
\hline
\end{tabular}


Table 5. Linkage disequilibrium between CYPs genes polymorphic markers

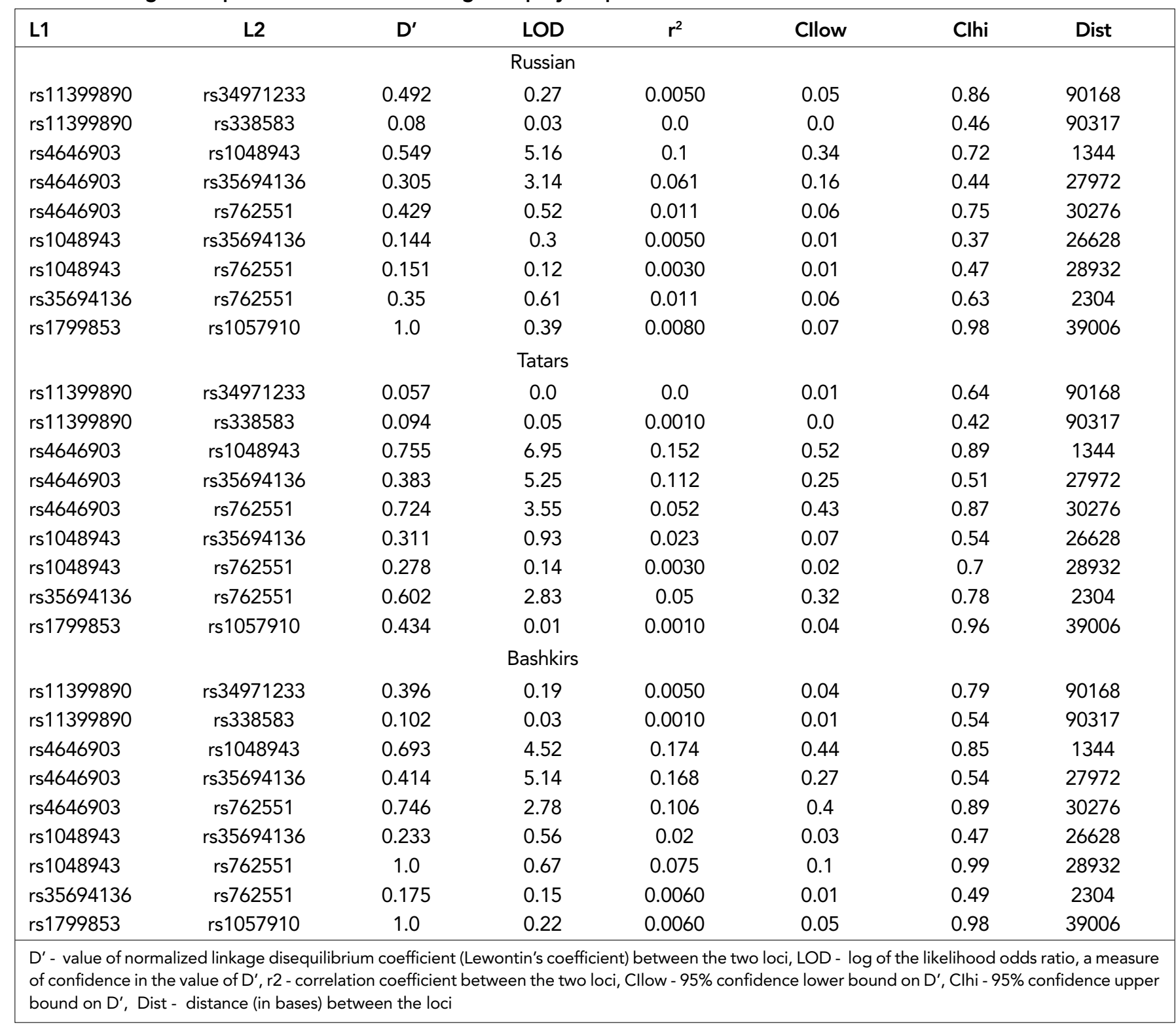

\section{CYP2S1 gene}

The CYP2S1 rs34971233, 13106C>T, P466L and rs338583, $13255 \mathrm{~A}>\mathrm{G}$ polymorphisms were detected by the PCR-RFLP method described by Saarikoski et al., [11] 2004. This method allows us to define simultaneously most common haplotypes (CYP2S1*1A, CYP2S1*1H, CYP2S1*3) of the CYP2S1. There was no significant difference in CYP2S1 haplotype frequencies between the ethnic groups (Table 4).

\section{Discussion}

The current study is the use of generalized data on the frequency of genotypes of CYPs in ethnic groups from the Republic of Bashkortostan (Russia).

CYP1A1 allele frequencies in Russians and Tatars were similar in the prevalence of the polymorphic variants of ( $r$ 1048943, 2454A > G) marker among Caucasians (5). The most significant interethnic differences were found among the eth- nic groups of the Republic of Bashkortostan and Mongoloid populations (5): Chinese (11, 12), Japanese (11, 12), Mexican Ancestry in LA, CA, USA (MEX) (HapMap), Han Chinese in Beijing, China (CHB) (HapMap). These differences were due to the high frequency of CYP1A $1{ }^{*} 2 \mathrm{C}$ allele reaching on the average $30 \%$ among Mongoloid populations, while the frequency of CYP1A $1 * 2 \mathrm{C}$ allele in African populations varied from 0 to $2.6 \%$ (5). For the ethnic group of Bashkirs, differences in the CYP1A1 polymorphism ( $r$ 1048943, 2454A>G) allele frequency distributions between them and Caucasian populations, as well as Mongoloid and African populations were statistically significant. Analysis of the published data showed that CYP1A1 polymorphism ( $r$ 1048943, 2454A>G) allele frequencies in Bashkirs were similar to those in Indians (13), Gujarati Indians in Houston, TX, USA (HapMap). Analysis of published data concerning CYP1A1 (rs4646903, 3798T>C) allele frequencies distribution showed that the ethnic groups of Russians, Tatars and Bashkirs differ significantly in terms of these markers from the gen- 
eral population of Caucasians, in which the CYP1A1*2A allele frequency was $9.40 \%(5)$ and Mongoloids, having a maximum frequency of CYP1A $1 * 2 A$ allele component around $39.47 \%(5$, $11,12)$. Africans and Indians are in an intermediate position, for them the frequency of minor allele does not exceed $26 \%$ $(5,14)$. The frequency of the CYP1A1*2A allele in Bashkirs was similar to that in populations of Indians (13) and Japanese (11, 12). A strict gradation in the pattern of the distribution of minor CYP1A $1 * 2 A$ allele has been detected, with a gradual increase in frequency in the following groups - Caucasians, Russian, Tatar, Bashkir, Africans, Indians, and Mongoloids. The frequency of the CYP1A1*2A haplotype of CYP1A1 was found to increase significantly in Bashkirs (15.77\%). The high frequency of haplotype CYP1A1*2B is typical for Mongoloids (5). Bashkirs were found to have the frequency of CYP1A1*2B haplotype $(7.69 \%)$, which places them between Mongoloids and Caucasians.

Individual variations of CYP1A2 levels are due to CYP1A2 genetic polymorphism $(14,15)$. The frequency of CYP1A2*1D allele among residents of the Republic of Bashkortostan was similar to the respective allele frequency among representatives of the Caucasians $-24.1 \%$ (NCBI,www.ncbi.nlm.nih.gov/ projects) and Italians - $24.0 \%$ (16). Among the British population, the frequency of allele CYP1A2*1D does not exceed $5.38 \%$ (16). Japanese and Egyptian populations, in contrast to Caucasian populations, showed higher frequencies of the CYP1A2*1D allele as $42-43.5 \%$ and $40 \%$, respectively $(17,18)$, for Africans and for the inhabitants of Oceania, the frequency of deletions reaches maximum values of 56.2 and $62.5 \%$ (NCBI, www.ncbi.nlm.nih.gov/projects/SNP). Comparative analysis of allele frequencies ( $r$ 762551, -163C >A) showed the similarity between the inhabitants of the Republic of Bashkortostan and the majority of worldwide populations. For Caucasians, Mongoloids and Africans the most frequent allele is the CYP1A2*1F $(15,16,18)$. Pairwise comparison revealed statistically significant differences in the distribution of allele frequencies among populations of Indians from Houston, U.S., Gujarati Indians in Houston, TX, USA (GIN) (HapMap) and residents of the Republic of Bashkortostan. These differences were associated with a low frequency of CYP1A2*1F allele (49.0\%) among Indians. Russians and Bashkirs differ from ethnic Mestizo ${ }^{1}$ inhabitants in Canada, since the Mestizo from Canada are characterized by high CYP1A2*1F allele frequency (70.22\%) (19). It has been shown that Tatars differ from the population of Yoruba in Ibadan, Nigeria (YRI) (HapMap), the frequency of the CYP1A2*1F allele is $57 \%$.

It is known that the patterns of the CYP1B1 polymorphic marker (rs1056836, 4326C> G, L432V) genotype frequencies distribution has significant racial differences (20-22). For Asian populations (Chinese, Japanese, Mexicans) it is very typical to observe the predominance of CYP1B1*1*1 genotype, which varies from 67 to $91 \%(20)$. In contrast, for Africans the most frequent genotype is CYP1B1*3*3,68\% in African Americans with the level of $87 \%$ in the Yoruba in Ibadan, Nigeria, YRI (HapMap) $(20,21)$. The Tatar ethnic group is significantly different in distribution from genotype frequencies of Caucasians living in England, but is similar to Caucasians in general $(20,22)$. Generally, Russians appear to differ significantly in allele frequencies of CYP1B1 from Caucasians. This result is explained by the presence of a higher frequency of CYP1B1*3 allele for the Russian ethnic group.
CYP2C9*2A (rs1799853, 3608C >T) and CYP2C9*3A ( $r$ 1057910, 42614A $>C$ ) polymorphisms occur in approximately $85 \%$ of poor metabolizers, and the frequency reported for white populations varies from $2 \%$ to $6 \%$ (23-25). Both CYP2C9*2A and CYP2C9*3A cause a reduction in S-warfarin clearance with 10 -fold variation observed from the genotype with the highest (CYP2C9*1A*1A) to the one with the lowest (CYP2C9*3A*3A) activity. The effect of the CYP2C9*3A*3A genotype is the most severe one, with the clearance of Swarfarin being $10 \%$ of the wild type genotype (26). According to results from this study, the prevalence of CYP2C9*2A and CYP2C9*3A alleles in Russians, Tatars and Bashkirs from the Republic of Bashkortostan are similar to Russians from the European part of Russia, Voronezh (10.5 and 6.7\%, respectively), Swedish (10.7 and 7.4\%), Turkish (10.6 and 10.0\%) and Greeks (12.9 and $8.13 \%)(24,25,27,28)$.

The CYP2E1 maps in region $10 q 24.3$ of chromosome $10(6,29)$. Allele CYP2E1*5B binds the transcription factors to the mutation region less efficiently, suggesting that the gene is less expressed in vivo in individuals carrying this allele (29). In the whole sample of Caucasians, the CYP2E1*5B allele of the CYP2E1 occurs with a frequency of $3.82 \%$ (5). Allele CYP2E1*5B binds the transcription factors to the mutation region less efficiently, suggesting that the gene is less expressed in vivo in individuals carrying this allele (29). In Czechs, the respective allele has a frequency of $2.3 \%$ (30). For those Caucasians representatives of CEPH, Utah residents with ancestry from northern and western Europe (CEU), it occurs with the frequency of $6 \%$ (HapMap), in Brazilian 5.5\%, Spanish 5.25\%, German 4.7\%, Italian $3.47 \%$ (31). In general, among Mongoloids the prevalence of the CYP2E1*5B allele reaches $22.53 \%$ (5). For the population of Chinese Han Chinese in Beijing, China (CHB) this is $-26 \%$ (HapMap), for Japanese -20.12\% (HapMap), for Mexicans Mexican Ancestry in LA, CA, USA (MEX) - 16\% (HapMap), and $20.5 \%$ in Taiwanese (31). For the representatives of the African population of Yoruba in Ibadan, Nigeria (YRI) this allele does not occur at all (HapMap). In the South Indian population it was only $1.3 \%$ (32). The frequency of allele CYP2E $1 * 5 B$ of the CYP2E1 ranged from $2.66 \%$ in Russians to $6.8 \%$ in Bashkirs. In Tatars, the value for this allele frequency was found to be between the values of the allele frequencies for Russians and Bashkirs $-4.84 \%$. Comparative analysis revealed a similarity of the inhabitants of the $\mathrm{Re}$ public of Bashkortostan to Caucasians and significant differences with Mongoloid populations.

In addition to the wild type CYP2F1*1 allele, seven other alleles have been characterized, including $C Y P 2 F 1 * 2 A$, CYP2F1*2B, CYP2F1*3, CYP2F1*4, CYP2F1*5A, CYP2F1*5B, and $C Y P 2 F 1 * 6$. The insertion c.14_15insC generates a premature stop codon in exon 2 and, consequently, leads to the synthesis of a substantially shorter protein product devoid of catalytic activity (33). For the ethnic group of Russians, differences in the genotype frequencies distribution of polymorphic marker c.14_15insC of the CYP2F1 were statistically significant for both populations of French, and Gabonese, as well as for Senegalese and Chinese (Guangdong population) (34, 35). Tatars and Bashkirs significantly differ from Senegalese and Gabonese, since those have a relatively high frequency of insertion allele (51.6 and $42.7 \%$, respectively) (34). How- 
ever, Tatar and Bashkir groups were statistically similar to the French and Chinese $(34,35)$. The frequency of insertion allele in Russians (17.63\%), Tatars (21.15\%) and in Bashkir (20.14\%) is relatively similar to that in Tunisians (22.9\%) (34).

A frequent substitution (-76G $>T$, rs890293) relative to the transcription start site, which interrupts a critical Sp1 binding site, results in both decreased promoter activity in vitro and reduced circulating levels of CYP2J2 epoxygenase metabolites (36). Comparative analysis of the polymorphic marker (rs890293, -76G> T) allele frequency of the CYP2J2 among ethnic groups of the Republic of Bashkortostan and populations across the world showed that the genotype and allele frequencies in Russians, Tatars and Bashkirs are similar in the prevalence of polymorphic variants of this marker among representatives of the Mongoloids (37-40). Particularly, all the Mongoloid populations are characterized by a high frequency of CYP2J2*1*1 genotype, which ranges from $88.5 \%$ in Japanese to $94.8 \%$ in Chinese (37-40). Low prevalence of allele CYP2J2*7 is also very typical in Mongoloids. Among them, the homozygous genotype CYP2J2*7*7 (0.8\%), was identified only in Japanese (38). This is the reason for significant differences in the genotypes and alleles frequency distribution observed between Japanese and Bashkirs. The population of Caucasians, in contrast, is characterized by a higher frequency of the presence of heterozygous genotype CYP2J2*1*7 (41). Individuals with homozygous CYP2J2*7*7 genotype were found in Germans and Spaniards $(0.7 \%$ and $3.9 \%$, respectively) $(37,42,43)$. For the Russians living in Kursk, the frequency of heterozygous genotype is quite low (2.3\%) (37), which explains their similarity to Bashkirs and dissimilarities compared to Russians and Tatars inhabiting the Republic of Bashkortostan. For Russians and Tatars, the genotypes and alleles frequency distribution of the CYP2J2 was significantly different from Spaniards and Americans, but was similar to Germans $(37,43,44)$. Bashkirs differed from all Caucasian populations. Comparison of the ethnic groups living in the Republic of Bashkortostan with AfricanAmericans showed that all the groups differ significantly (44).

Comparative analysis of the polymorphic marker (rs338583, 13255A > G) allele frequency of the CYP2S1 among ethnic groups of the Republic of Bashkortostan and populations across the world showed that the genotype and allele frequencies in Russians, Tatars and Bashkirs are similar in the prevalence of polymorphic variants of this marker among representatives of the Caucasians representatives of $\mathrm{CEPH}$, Utah residents with ancestry from northern and western Europe (CEU) (26\%) (HapMap), Mexicans Mexican Ancestry in LA, CA, USA (MEX) -23\% (HapMap) and Japanese in Tokyo and Japan (JPT) $-23 \%$ (HapMap).

\section{Conclusion}

Analyses of individual phenotypes and genotypes for the genes responsible for sensitivity to xenobiotics pointed to racial, ethnic, and geographical differences in the responses to pharmaceuticals and other toxic compounds. In this context, especially in Russia, which is a multinational state, evaluation of the population frequencies of the gene variants responsible for xenobiotic transformation are essential for further investigation of complex diseases and determination of the roles of climatic and geographical condition in their development.
We demonstrated interethnic differences in the genotype, allele, and haplotype frequency distributions of the CYP1A1, CYP1A2, and CYP2E1 genes. Bashkirs differed from both Tatars and Russians in the CYP1A1, CYP1A2 haplotype frequencies owing to a relatively high frequency of rare alleles and haplotypes of both genes. These peculiarities of the allele frequency distribution of xenobiotic biotransformation genes, including the cytochrome P450 genes, in Bashkirs should be taken into consideration in association and pharmacogenetic studies. The results of the present investigation will form the basis for identification of the genetic risk factors to cancer susceptibility, as well as in determining the toxic potentials of environmental pollutants.

\section{Acknowledgements}

This work was supported by the Russian Foundation for Humanities (project no. 07-06-00058a) and the Russian Foundation for Basic Research (project no. 08-04-87007-rpovolzh'e-a).

\section{Conflict of Interest}

No conflict of interest was declared by the authors.

\section{References}

1. Nelson DR. The cytochrome p450 homepage. Hum Genomics 2009;4:59-65.

2. Ingelman-Sundberg M. Human drug metabolising cytochrome P450 enzymes: properties and polymorphism. Naunyn Schmiedebergs Arch Pharmacol 2004;369:89-104. [CrossRef]

3. Rodriguez-Antona C, Gomez A, Karlgren M, Sim SC, IngelmanSundberg M. Molecular genetics and epigenetics of the cytochrome P450 gene family and its relevance for cancer risk and treatment. Hum Genet 2010;127:1-17. [CrossRef]

4. Hukkanen J, Pelkonen O, Hakkola J, Raunio H. Expression and regulation of xenobiotic-metabolizing cytochrome P450 (CYP) enzymes in human lung. Crit Rev Toxicol 2002;32:391-411. [CrossRef]

5. Garte S, Gaspari L, Alexandrie AK, Ambrosone C, Autrup H, Autrup $\mathrm{JL}$, et al. Metabolic gene polymorphism frequencies in control populations. Cancer Epidemiol Biomarkers Prev 2001;10:1239-48.

6. Borinskaya SA, Khusnutdinova E. Ethnogenomics: history and geography. 2002; 1: 19-30 (in Russ.).

7. Limborska SA, Khusnutdinova EK. Ethnogenomics of the peoples of the Volga-Ural's region. Moscow: Nauka Publ. 2002; 250. (in Russ.).

8. Bartsch H, Nair U, Risch A, Rojas M, Wikman H, Alexandrov K. Genetic polymorphism of CYP genes, alone or in combination, as a risk modifier of tobacco-related cancers. Cancer Epidemiol Biomarkers Prev 2000;9:3-28.

9. Mathew C.C. The isolation of high molecular weight eucariotic DNA // Methods in molecular biology / Ed. Walker J.M. N.Y.; Haman press, 1984. -V.2. - P.31-4.

10. Barrett JC, Fry B, Maller J, Daly MJ. Haploview: analysis and visualization of $L D$ and haplotype maps. Bioinformatics 2005;21:2635. [CrossRef]

11. Saarikoski ST, Suitiala T, Holmila R, Impivaara $O$, Järvisalo J, Hirvonen $A$, et al. Identification of genetic polymorphisms of CYP2S1 in a Finnish Caucasian population. Mutat Res 2004;554:267-77. [CrossRef]

12. Wang LD, Zheng S, Liu B, Zhou JX, Li YJ, Li JX. CYP1A1, GSTs and $\mathrm{mEH}$ polymorphisms and susceptibility to esophageal carcinoma: study of population from a high- incidence area in north China. World J Gastroenterol 2003;9:1394-7.

13. Buch S, Kotekar A, Kawle D, Bhisey R. Polymorphisms at CYP and GST gene loci. Prevalence in the Indian population. Eur J Clin Pharmacol 2001;57:553-5.

14. Murayama N, Soyama A, Saito Y, Nakajima Y, Komamura K, Ueno $\mathrm{K}$, et al. Six novel nonsynonymous CYP1A2 gene polymorphism: 
catalytic activites of the naturally occurring variant enzymes. J Pharmacol Exp Ther 2004;308:300-06. [CrossRef]

15. Sachse C, Bhambra U, Smith G, Lightfoot TJ, Barrett JH, Scollay $\mathrm{J}$, et al. Polymorphisms in the cytochrome P450 CYP1A2 gene (CYP1A2) in colorectal cancer patients and controls: allele frequencies, linkage disequilibrium and influence on caffeine metabolism. Br J Clin Pharmacol 2003; 55:68-76. [CrossRef]

16. Pavanello $S$, Pulliero $A$, Lupi $S$, Gregorio $P$, Clonfero E. Influence of the genetic polymorphism in the $5^{\prime}$-noncoding region of the CYP1A2 gene on CYP1A2 phenotype and urinary mutagenicity in smokers. Mutat Res 2005;10:59-66.

17. Chida M, Yokoi T, Fukui T, Kinoshita M, Yokota J, Kamataki T. Detection of three genetic polymorphisms in the $5^{\prime}$-flanking region and intron 1 of human CYP1A2 in the Japanese population. Jpn J Cancer Res 1999;90,899-902. [CrossRef]

18. Soyama A, Saito Y, Hanioka N, Maekawa K, Komamura K, Kamakura $S$, et al. Single nucleotide polymorphisms and haplotypes of CYP1A2 in a Japanese population. Drug Metab Pharmacokinet 2005;20,24-33. [CrossRef]

19. Cornelis MC, El-Sohemy A, Campos H. Genetic polymorphism of CYP1A2 increases the risk of myocardial infarction. J Med Genet 2004;41,758-6. [CrossRef]

20. Paracchini V, Raimondi S, Gram IT, Kang D, Kocabas NA, Kristensen $\mathrm{VN}$, et al. Meta- and pooled analyses of the cytochrome P-450 1B1 Val432Leu polymorphism and breast cancer: a HuGE-GSEC review. Am J Epidemiol 2007;165,115-25. [CrossRef]

21. Bailey LR, Roodi N, Dupont WD, Parl FF. Association of cytochrome P450 1B1 (CYP1B1) polymorphism with steroid receptor status in breast cancer. Cancer Res 1998;58,5038-41.

22. Bethke L, Webb E, Sellick G, Rudd M, Penegar S, Withey L, et al. Polymorphisms in the cytochrome P450 genes CYP1A2, CYP1B1, CYP3A4, CYP3A5, CYP11A1, CYP17A1, CYP19A1 and colorectal cancer risk. BMC Cancer 2007;7:123. [CrossRef]

23. Arvanitidis K, Ragia G, lordanidou M, Kyriaki S, Xanthi A, Tavridou A, et al. Genetic polymorphisms of drug-metabolizing enzymes CYP2D6, CYP2C9, CYP2C19 and CYP3A5 in the Greek population. Fundam Clin Pharmacol 2007;21:419-26. [CrossRef]

24. Bozina N, Grani冈 P, Lali囚 Z, Tramisak I, Lovri囚 M, Stavljeni囚Rukavina A. Genetic polymorphisms of cytochromes P450: CYP2C9, CYP2C19, and CYP2D6 in Croatian population. Croat Med J 2003; 44:425-8.

25. Gaikovitch EA, Cascorbi I, Mrozikiewicz PM, Brockmöller J, Frötschl R, Köpke K, et al. Polymorphisms of drug-metabolizing enzymes CYP2C9, CYP2C19, CYP2D6, CYP1A1, NAT2 and of P-glycoprotein in a Russian population. Eur J Clin Pharmacol 2003;59:303-12. [CrossRef]

26. Scordo MG, Pengo V, Spina E, Dahl ML, Gusella M, Padrini R. Influence of CYP2C9 and CYP2C19 genetic polymorphisms on warfarin maintenance dose and metabolic clearance. Clin Pharmacol Ther 2002;72:702-10. [CrossRef]

27. Yasar U, Eliasson E, Dahl ML, Johansson I, Ingelman-Sundberg M, Sjöqvist F. Validation of methods for CYP2C9 genotyping: frequencies of mutant alleles in a Swedish population. Biochem Biophys Res Commun 1999;254:628-31. [CrossRef]

28. Aynacioglu AS, Brockmöller J, Bauer S, Sachse C, Güzelbey P, Ongen Z, et al. Frequency of cytochrome P450 CYP2C9 variants in a Turkish population and functional relevance for phenytoin, $\mathrm{Br}$ J Clin Pharmacol 1999;48:409-15. [CrossRef]

29. Kolble K. Regional mapping of short tandem repeats on human chromosome 10: Cytochrome P450 gene CYP2E, D10S196,
D10S220, and D10S225. Genomics 1993;18:702-4. [CrossRef]

30. Sarmanová J, Tynková L, Süsová S, Gut I, Soucek P. Genetic polymorphisms of biotransformation enzymes: allele frequencies in the population of the Czech Republic. Pharmacogenetics 2000;10:781. [CrossRef]

31. Tang K, Li Y, Zhang Z, Gu Y, Xiong Y, Feng G, et al. The Pstl/Rsal and Dral polymorphisms of CYP2E1 and head and neck cancer risk: a meta-analysis based on 21 case-control studies. BMC Cancer 2010;10:575. [CrossRef]

32. Krishnakumar D, Gurusamy U, Dhandapani K, Surendiran A, Baghel $R$, Kukreti $R$, et al. Genetic polymorphisms of drug-metabolizing phase I enzymes CYP2E1, CYP2A6 and CYP3A5 in South Indian population. Fundam Clin Pharmacol 2012;26:295-306. [CrossRef]

33. Tournel G, Cauffiez C, Billaut-Laden I, Allorge D, Chevalier $\mathrm{D}$, Bonnifet $\mathrm{F}$, et al. Molecular analysis of the CYP2F1 gene: identification of a frequent non-functional allelic variant. Mutat Res 2007;617:79-89. [CrossRef]

34. Tournel G, Cauffiez C, Leclerc J, Billaut-Laden I, Allorge D, Chevalier D, et al. CYP2F1 genetic polymorphism: identification of interethnic variations. Xenobiotica 2007;37:1433-8. [CrossRef]

35. Jiang JH, Li Z, Su G, Jia WH, Zhang RH, Yu XJ, et al. Study on genetic polymorphisms of CYP2F1 gene in Guangdong population of China. Zhonghua Yi Xue Yi Chuan Xue Za Zhi 2006;23:383-7.

36. Polonikov AV, Ivanov VP, Solodilova MA, Khoroshaya IV Kozhuhov MA, Panfilov VI. Promoter polymorphism G-50T of a human CYP2J2 epoxygenase gene is associated with common susceptibility to asthma. Chest 2007;132:120-6. [CrossRef]

37. Spiecker M, Darius $H$, Hankeln T, Soufi M, Sattler AM, Schaefer $J R$, et al. Risk of coronary artery disease associated with polymorphism of the cytochrome P450 epoxygenase CYP2J2. Circulation 2004;110:2132-6. [CrossRef]

38. Takeshita H, Tsubota E, Takatsuka H, Kunito T, Fujihara J. Cytochrome P450 2J2*7 polymorphisms in Japanese, Mongolians and Ovambos. Cell Biochem Funct 2008;26:813-6. [CrossRef]

39. Lee SS, Jeong HE, Liu KH, Ryu JY, Moon T, Yoon CN, et al. Identification and functional characterization of novel CYP2J2 variants: G312R variant causes loss of enzyme catalytic activity. Pharmacogenet Genomics 2005;15:105-13. [CrossRef]

40. Wang $\mathrm{H}$, Jiang $Y$, Liu $Y$, Lin $C$, Cheng G, Chen $X$, et al. CYP2J2*7 single nucleotide polymorphism in a Chinese population. Clin Chim Acta 2006;365:125-8. [CrossRef]

41. Rylander $T$, Neve $E P$, Ingelman-Sundberg $M$, Oscarson $M$. Identification and tissue distribution of the novel human cytochrome P450 2S1 (CYP2S1). Biochem Biophys Res Commun 2001;281:529-35. [CrossRef]

42. Hoffman SM, Nelson DR, Keeney DS. Organization, structure and evolution of the CYP2 gene cluster on human chromosome 19. Pharmacogenetics 2001;11:687-98. [CrossRef]

43. Gervasini G, Vizcaino S, Carrillo JA, Caballero MJ, Benitez J. The effect of CYP2J2, CYP3A4, CYP3A5 and the MDR1 polymorphisms and gender on the urinary excretion of the metabolites of the $\mathrm{H}$-receptor antihistamine ebastine: a pilot study. Br J Clin Pharmacol 2006;62:177-86. [CrossRef]

44. King LM, Gainer JV, David GL, Dai D, Goldstein JA, Brown NJ, et al. Single nucleotide polymorphisms in the CYP2J2 and CYP2C8 genes and the risk of hypertension. Pharmacogenet Genomics 2005;15:7-13. [CrossRef] 